\title{
A Preliminary Quantitative Study of the Mysticism and Religious Maturity of Contemporary Slavic Neopagans in Poland
}

\section{KONRAD KOŚNIK - ELŻBIETA HORNOWSKA}

Slavic Neopaganism (Rodnovery) is a new religious movement that forms part of Neopaganism. This phenomenon is defined in scientific literature as "Neopaganism"; however, the term itself does not precisely account for the differences that can be observed between Slavic Neopaganism and other Neopagan groups. Additionally, it raises objections on the part of Rodnovers themselves who, due to the Christian origin of the term "(neo)Pagans", do not want to be identified with it. ${ }^{1}$ Regardless of how this movement is called, it constitutes an attempt to rebuild the ethnic, pre-Christian religion of ancient (early medieval) Slavs, taking into consideration its polytheism and rites, as well as the way of perceiving reality. ${ }^{2}$ In this paper both the terms Slavic Neopaganism and Rodnovery are treated as synonyms. Information about the beliefs of remote ancestors is drawn by Slavic Neopagans from historical, archeological, and ethnographic sources. A scarcity of data forces the followers of Rodnovery to conduct reconstructions of religious content and to make generalizations based on preserved information. The religious current that can be encountered in all Slavic countries, despite the relatively small numbers of adher-

1 Konrad Kośnik, “Tożsamość współczesnych rodzimowierców słowiańskich: Studium psychologiczne aktywności internetowej rodzimowierców w Polsce”, Przegląd Religioznawczy 2015/3 (257), 2015, 119-134; Milan Petrović, "Qualification of Slavic Rodnovery in Scientific Literature - Neopaganism or Ethnic Religion" [online], $<$ http://svevlad.org.rs/rodoved_files/petrovic_qualification\%20_of_slavic_rodnovery_ in_scientific_literature.pdf>, March 2013 [28 December 2019]; Maciej Strutyński, Neopogaństwo, Kraków: Wydawnictwo WAM 2014.

2 Paul M. Barford, The Early Slavs: Culture and Society in Early Medieval Eastern Europe, Ithaca - New York: Cornell University Press 2001; Aleksander Gieysztor, Mitologia Stowian, Warszawa: Wydawnictwa Uniwersytetu Warszawskiego 2006; Andrzej Szyjewski, Religia Stowian, Kraków: Wydawnictwo WAM 2010. 
ents in Poland (app. 7000-10000), remains internally divided. The reason for this stems from the doctrine as well as from political views and sympathies. In Poland, the Rodnovery movement is focused around three main, officially-registered faith organizations. ${ }^{3}$

The roots of contemporary Slavic Neopaganism in Poland reach back to the $19^{\text {th }}$ century's (Romantic) interest in folk culture and the search for a Polish national identity based on Slavic values. The relationship between Rodnovery and social identity is the very thing that makes this phenomenon so important and generates a need to explore it in psychological terms. Slavic Neopaganism, as one of the indicators of the Slavic identity of Poles, constitutes an important source of knowledge about the processes of forming an ethnic and national identity, as well as a religious one. For, to this religious movement belong individuals who seek to discover their own identity, taking into consideration native (remote or ancient) cultural content, which is typical of postcolonial societies. ${ }^{4}$ Conducting studies on Rodnovery can be regarded as making a contribution to the building of a "Pagan theology", i.e. (unconsciously) supporting Neopagans in constructing their religious doctrine. ${ }^{5}$ Therefore, when researching this phenomenon, care must be taken to conduct critical analysis distanced from possible evaluative connotations and not to demonstrate the superiority of Rodnovery over a dominant religious group (in this case: Catholics).

In the article, we present the results of study on the spirituality of Slavic Neopagans in Poland in reference to questions of differences between Slavic Neopagans and Catholics (as a dominant religious group) and pre-

3 Mariusz Filip, "Native Faith (Not) Only for Men: Gendering Extreme Right-Wing Slavic Neopaganism in Poland", Pantheon: Religionistický časopis 10/1, 2015, 56-78; K. Kośnik, "Tożsamość współczesnych rodzimowierców...”; M. Strutyński, Neopogaństwo...

4 The postcolonial character of Polish society refers to the lack of independence after the third partition of the Polish-Lithuanian Commonwealth (1795-1918) as well as to the Communist government subordinated to the Soviet Union after the World War II (until 1989); Andrzej Pankalla - Konrad Kośnik, "Slavic Indigenous Psychology as a Science about the Slavic Soul", Psychology and Personality 2/10 (part 1), 2016, 21-31; Andrzej Pankalla - Konrad Kośnik, "Religion as an Invaluable Source of Psychological Knowledge: Indigenous Slavic Psychology of Religion", Journal of Theoretical and Philosophical Psychology 38/3, 2018, 154-164; Andrzej Pankalla - Konrad Kośnik Jacek Stasiorczyk, "Psychological Anthropology of the Early Slavs: Re-Construction of the Slavic (Indigenous) Psychological Conception of Human Development", under review in Revista de Historia de la Psicología; Piotr Wiench, "A Postcolonial Key to Understanding Central and Eastern European Neopaganisms", in: Kaarina Aitamurto - Scott Simpson (eds.), Modern Pagan and Native Faith Movements in Central and Eastern Europe, Durham: Acumen 2013, 10-26.

5 Markus A. Davidsen, "What is Wrong with Pagan Studies?", Method and Theory in the Study of Religion 24, 2012, 183-199. 
dictors of belonging to Rodnovery. The selection of spirituality as the main theoretical construct is dictated by its central meaning for the issues of both religiousness and the identity of Slavic Neopagans. States of spirituality, for this group of people, are related to a neophytic engagement in their own Slavicness that has not been inculcated in them by their parents in the process of their upbringing (they are the first generation of Slavic Neopagans in Poland). This Slavic identity, both in the religious and ethno-national aspects, is constructed by such individuals ad hoc.

The spiritual experiences of Slavic Neopagans are a result of their search for their identity as well as of the answers to existential questions about local, indigenous and cultural content. ${ }^{6}$ The spirituality of Rodnovers, investigated with the use of Ralph W. Hood Jr.'s concept of mysticism, ${ }^{7}$ has been compared to the construct of religious maturity according to Roger L. Dudley and Robert J. Cruise. ${ }^{8}$ The decision to confront these two constructs was based on the desire to verify to what extent belonging to the Rodnovery community stems from a juvenile "whim" and to what extent it is associated with a real and mature need to realize oneself in a particular religious current. Another argument is that a vast majority of concepts in the field of the psychology of religion and spirituality, as well as research tools based on these concepts, were developed in the Christian tradition and present difficulties during their adaptation to different religions. This is why we decided to use the concepts of mysticism and religious maturity - to make the preliminary (exploratory) quantitative study possible and to create a basis for further conceptual adaptations in Rodnovery research.

6 Konrad Kośnik, W poszukiwaniu duchowości: Studium psychologiczne współczesnych rodzimowierców stowiańskich w Polsce [manuscript of a M.A. thesis], Poznań: Adam Mickiewicz University in Poznań 2016; Scott Simpson, "Strategies for Constructing Religious Practice in Polish Rodzimowierstwo", in: Adam Anczyk - Halina GrzymałaMoszczyńska (eds.), Walking the Old Ways: Studies in Contemporary European Paganism, Katowice: Sacrum Publishing House 2012, 11-36; Scott Simpson, "Men Constructing Masculinity in Polish Rodzimowierstwo: Tradition and Nature", Pantheon: Religionistický časopis 10/1, 2015, 3-20.

7 Ralph W. Hood Jr., "The Construction and Preliminary Validation of a Measure of Reported Mystical Experience", Journal for the Scientific Study of Religion 14/1, 1975 , 29-41.

8 Roger L. Dudley - Robert J. Cruise, "Measuring Religious Maturity: A Proposed Scale", Review of Religious Research 32/2, 1990, 97-109. 


\section{Theoretical background}

\subsection{Slavic Neopagans and spirituality}

In the face of the secularization of Western societies as well as due to vocalized (also among scientific groups) manifestations of rational atheism, ${ }^{9}$ spirituality and religiousness are generally understood as separate phenomena. This can lead to a situation in which an individual experiences spiritual phenomena despite the lack of any religious experiences. ${ }^{10}$ In practice, however, these two notions are strongly connected. The majority of Americans perceive themselves as both spiritualized and religious, understanding these two terms similarly. ${ }^{11}$ Nevertheless, there exist differences between spirituality and religiousness. Religiousness is understood rather in behavioral and institutional terms - e.g. going to church, reading the Bible, ${ }^{12}$ whereas spirituality, in experiential terms - e.g. possessing a sense of connection with a supernatural entity or force. ${ }^{13}$ According to Beck, ${ }^{14}$ spirituality is important for both religious and non-religious people, because spiritualized people are characterized by such traits as courage, acceptance, and energy, being also considered to have a broad and holistic worldview. Piedmont ${ }^{15}$ suggested treating spirituality as the

9 André Comte-Sponville, The Book of Atheist Spirituality: An Elegant Argument for Spirituality without God, London: Bantam Books 2009; Richard Dawkins, The God Delusion, London: Bantam Press 2006.

10 Doug Oman, "Defining Religion and Spirituality", in: Raymond F. Paloutzian Crystal L. Park (eds.), Handbook of the Psychology of Religion and Spirituality (Second Edition), New York - London: The Guilford Press 2013, 23-47; David M. Wulff, Psychology of Religion: Classic and Contemporary, New York: John Wiley and Sons 1997; Brian J. Zinnbauer - Kenneth I. Pargament - Allie B. Scott, "The Emerging Meaning of Religiousness and Spirituality: Problems and Prospects", Journal of Personality 67, 1999, 889-919.

11 Penny L. Marler - C. Kirk Hadaway, “'Being Religious' or 'Being Spiritual' in America: A Zero-Sum Proposition?”, Journal for the Scientific Study of Religion 41/2, 2002, 289-300; Lawrence J. Walker - Russell C. Pitts, "Naturalistic Conceptions of Moral Maturity", Developmental Psychology 34/3, 1998, 403-419.

12 L. J. Walker - R. C. Pitts, "Naturalistic Conceptions...".

13 Brian J. Zinnbauer - Kenneth I. Pargament, "Religiousness and Spirituality", in: Raymond F. Paloutzian - Crystal L. Park (eds.), Handbook of the Psychology of Religion and Spirituality, New York - London: The Guilford Press 2005, 21-42.

14 Clive Beck, "Education for Spirituality”, Interchange 17, 1986, 148-156.

15 Ralph L. Piedmont, "Does Spirituality Represent the Sixth Factor of Personality? Spiritual Transcendence and the Five-Factor Model", Journal of Personality 67/6, 1999, 985-1013. 
sixth personality dimension in the Costa and McCrae Big Five model. Furthermore, spirituality can be understood as a form of intelligence. ${ }^{16}$

Analyzing the issue of the spirituality of Slavic Neopagans in Poland, we cannot omit the issue of social identity, which is closely connected to the contemporary, dynamic processes of re-thinking and finding new objects of self-identification, due to the postcolonial character of Polish society. ${ }^{17}$ Rodnovers can be seen as "the more Slavic" Poles due to the fact that they devote such intimate spheres of their lives as religiousness and spirituality to Slavic values, and create a different, neo-traditional identity. They form part of a broader tendency to search for an answer to the question about the essence of Polishness in Slavic (pre-Christian) cultural content. ${ }^{18}$ Contemporary pop culture in Poland, especially on the Internet, has become more and more saturated with "Slavicness". This can be observed, for instance, in pop art (music, literature, etc.) or in amateurish historical narratives. ${ }^{19}$ Therefore, the search for spirituality by Rodnovers, besides typically striving for mystical experiences, can be interpreted as an attempt to find one's essence in an indigenous (anti-globalized) cultural context, for their spiritual experiences are connected with what is native (Slavic, Polish) - for instance, with local deities and traditional Slavic devotion to the natural environment.

\subsection{Mysticism according to Ralph W. Hood Jr.}

Mystical experiences refer to a state of feeling united with a supernatural reality, a loss of the boundaries of one's Self, and a lack of the sense of time and space. They are not linked to the current situation of the person who experiences them, and they do not pertain to the direct context of the particular religion. ${ }^{20}$ They appear in both natural environments as well as

16 Robert A. Emmons, "Is Spirituality an Intelligence? Motivation, Cognition, and the Psychology of Ultimate Concern", The International Journal for the Psychology of Religion 10/1, 2000, 3-26.

17 Konrad Kośnik, "Internetowe narracje historyczne a słowiańska tożsamość Polaków: Prolegomena teoretyczna", Sensus Historiae 30/1, 2018, 57-68; P. Wiench, "A Postcolonial Key...".

18 K. Kośnik, "Internetowe narracje historyczne...”; Konrad Kośnik - Jacek Stasiorczyk, "Psycho-kulturowe uwarunkowania poglądów geopolitycznych: Polscy rodzimowiercy słowiańscy a wojna w Donbasie", Contemporary Trends in International Relations: Politics, Economics, Law 6/18, 2016, 238-248.

19 Konrad Kośnik - Justyna Filipiuk, "Słowiańskie teorie spiskowe jako pozanaukowe narracje historyczne", Czas Kultury 2/189, 2016, 82-90.

20 R. W. Hood Jr., "The Construction..."; Ralph W. Hood Jr. - Peter C. Hill - Bernard Spilka, The Psychology of Religion: An Empirical Approach, New York - London: The Guilford Press 2009, 331-337; William James, The Varieties of Religious Experience: A Study in Human Nature, New York: Touchstone 2004 ( $1^{\text {st }}$ ed. 1902), 281-318. 
those strongly processed by humans, in both cases remaining in a relationship with the psychological well-being of the person. ${ }^{21}$

Based on the philosophical and theological tradition of Walter Stace, ${ }^{22}$ the theoretical concept put forward by Hood ${ }^{23}$ assumes the universal character of mystical experiences, which in a phenomenological sense remain independent of their ideological interpretation. Categories localized in the theoretically described core of mysticism, according to a person's prior experiences, find their individual realization in the person's mystical experience. ${ }^{24}$ The starting point for the psychological investigations of mysticism conducted by $\mathrm{Hood}^{25}$ were studies focused on the psychedelic states that appear after the use of psychoactive substances, classified as mystical experiences. They also inspired the search for a broader context of spiritual experiences treated as being independent of any particular religious system.

A comparison of religious contemplatives, psychotic inpatients, and normal adults by means of the Mysticism Scale, a tool devised by Hood, ${ }^{26}$ showed that the group of normal adults differed from the remaining two groups (lower mean score); however, the latter two groups did not differ from each other. ${ }^{27}$ A relationship between positive schizotypy and mysticism was also demonstrated, this correlation turning out to be stronger in the case of the experiential aspect than the interpretative aspect of mysticism. ${ }^{28}$ Comparative studies of Christian, Islamic, and Hindu believers showed differences in terms of vertical mysticism (noetic quality and ineffability). Hindus were characterized by a lower engagement in vertical mysticism than Christians and Muslims, although in principle it plays a pivotal role in their religion. ${ }^{29}$ A study conducted on Chinese Christians

21 Tristan L. Snell - Janette G. Simmonds, "Mystical Experiences in Nature: Comparing Outcomes for Psychological Well-being and Environmental Behaviour", Archive for the Psychology of Religion 37/2, 2015, 169-184.

22 Walter T. Stace, Mysticism and Philosophy, Philadelphia: J.B. Lippincott 1960.

23 R. W. Hood Jr., "The Construction...".

24 R. W. Hood Jr. - P. C. Hill - B. Spilka, The Psychology of Religion..., 365-368.

25 R. W. Hood Jr., "The Construction...".

26 Ibid.

27 Kenneth Stifler - Joanne Greer - William Sneck - Robert Dovenmuehle, "An Empirical Investigation of the Discriminability of Reported Mystical Experiences among Religious Contemplatives, Psychotic Inpatients, and Normal Adults”, Journal for the Scientific Study of Religion 32/4, 1993, 366-372.

28 Greg N. Byrom, "Differential Relationships between Experiential and Interpretive Dimensions of Mysticism and Schizotypal Magical Ideation in a University Sample", Archive for the Psychology of Religion 31/2, 2009, 127-150.

29 Francis-Vincent Anthony - Chris A. M. Hermans - Carl Sterkens, "A Comparative Study of Mystical Experience among Christian, Muslim, and Hindu Students in Tamil Nadu, India", Journal for the Scientific Study of Religion 49/2, 2010, 264-277. 
and non-Christians showed that both of these groups were characterized by high indicators of mysticism; however, Christians would interpret their spiritual experiences in religious categories more often. ${ }^{30}$ In turn, studies conducted on a group of Anglican priests showed a positive relationship between mystical orientation and extraversion in the understanding of Eysenck; however, there was no correlation with neuroticism or psychoticism. $^{31}$

Hood distinguished eight dimensions of mysticism in his theory. ${ }^{32}$ The factorial analyses described in psychological literature suggest, however, a lower number of these dimensions. Hood himself also pointed to the possibility of distinguishing two factors: general mysticism and religious interpretation. ${ }^{33}$ According to Caird, the interpretative factor of mysticism should be divided into a noetic dimension and a religious dimension, which in consequence would result in distinguishing three factors. ${ }^{34}$ The three-factor conceptualization of mysticism was also undertaken by Hood in his later studies. ${ }^{35}$ The author distinguished between extrovertive mysticism, religious interpretation, and introvertive mysticism. This division was confirmed on a sample of American and Iranian Muslims. ${ }^{36}$ In turn, in a study conducted on individuals who consumed hallucinatory substances, four factors were observed: (F1) unity, noetic quality, and sacredness; (F2) positive mood; (F3) transcendence of time/space; (F4) ineffability. ${ }^{37}$ Owing to the considerable differences in the results of the factorial

30 Zhuo Chen - Yang Zhang - Ralph W. Hood Jr. - Paul J. Watson, "Mysticism in Chinese Christians and Non-Christians: Measurement Invariance of the Mysticism Scale and Implications for the Mean Differences", The International Journal for the Psychology of Religion 22/2, 2012, 155-168.

31 Leslie J. Francis - T. Hugh Thomas, "Mystical Orientation and Personality among Anglican Clergy", Pastoral Psychology 45/2, 1996, 99-105.

32 R. W. Hood Jr., "The Construction...".

33 Ibid.

34 Dale Caird, "The Structure of Hood's Mysticism Scale: A Factor-Analytic Study", Journal for the Scientific Study of Religion 27/1, 1988, 122-126; Duane F. Reinert Kenneth R. Stifler, "Hood's Mysticism Scale Revisited: A Factor-Analytic Replication", Journal for the Scientific Study of Religion 32/4, 1993, 383-388.

35 Ralph W. Hood Jr. - Ronald J. Morris - Paul J. Watson, "Further Factor Analysis of Hood's Mysticism Scale”, Psychological Reports 73, 1993, 1176-1178; Ralph W. Hood Jr. - Zhuo Chen, "Mystical, Spiritual, and Religious Experiences", in: Raymond F. Paloutzian - Crystal L. Park (eds.), Handbook of the Psychology of Religion and Spirituality (Second Edition), New York - London: The Guilford Press 2013, 422-440.

36 Ralph W. Hood Jr. - Nima Ghorbani - Paul J. Watson et al., "Dimensions of the Mysticism Scale: Confirming the Three-Factor Structure in the United States and Iran", Journal for the Scientific Study of Religion 40/4, 2001, 691-705.

37 Katherine A. Maclean - Jeannie-Marie S. Leoutsakos - Matthew W. Johnson - Roland R. Griffiths, "Factor Analysis of the Mystical Experience Questionnaire: A Study of Experiences Occasioned by the Hallucinogen Psilocybin", Journal for the Scientific Study of Religion 51/4, 2012, 721-737. 
analyses conducted so far, we decided to use the original, eight-factor division of mystical states. Due to its strong foundation in the philosophical and psychological tradition of studies on mysticism, it allows us to interpret the obtained results in more theoretical ways than a strictly statistical one. Thus:

- Ego Quality describes a sense of losing oneself despite the fact that consciousness is preserved. This state of losing oneself is often experienced as being absorbed by an external object that is more powerful than the Self.

- Unifying Quality is a sense of unity, an experience of perceiving all (many) objects as united into a common whole. It is accompanied by an inability to differentiate between particular objects.

- Inner Subjective Quality refers to perceiving objects as animate and to having a conviction about the internal subjectivity of all objects present in the surrounding environment, including those generally perceived as purely material. These objects are perceived as living entities, possessing their own consciousness.

- Temporal/Spatial Quality describes losing a sense of space and time. In the person's perception, time and space become distorted or disappear entirely.

- Noetic Quality is a sense of enlightenment, and the person's experience is the source of noetic cognition. The person then acquires new and important, although intuitive and supra-rational, knowledge of the world.

- Ineffability is the dimension describing the difficulties in expressing one's experiences through the use of conventional (verbal) forms of communication. The person is unable to put the content of his/her experiences into words due to the essence of the very experience.

- Positive Affect refers to a person's experience of positive affectivity that can take the form of all-embracing happiness, blissfulness, or calmness.

- Religious Quality pertains to experiencing a sense of holiness or miraculousness with reference to a religious interpretation of a mystical experience, which can, but does not have to, be based on the tradition of a particular religion. ${ }^{38}$

38 Christopher T. Burris, "The Mysticism Scale: Research Form D (M Scale)", in: Peter C. Hill - Ralph W. Hood Jr. (eds.), Measures of Religiosity, Birmingham: Religious Education Press 1999, 363-367; R. W. Hood Jr., "The Construction...". 


\subsection{Religious maturity according to Roger L. Dudley and Robert J. Cruise}

The notion of religious maturity pertains to the creative tension between sincere religious commitment and open-mindedness which is filled with doubt about the validity of one's beliefs. ${ }^{39}$ The search for creative solutions that aim to preserve the balance between the two states is the result of such a tension. Open-mindedness is not understood here as doubt regarding the validity of one's beliefs (which would exclude being internally engaged), but as the readiness to revise one's beliefs in the case of acquiring new knowledge; although doubt plays an important role in the acquisition of a religious identity. ${ }^{40}$ Cole and Wortham ${ }^{41}$ conducted a critical evaluation of treating religious maturity as a homogeneous synthesis of engagement and open-mindedness; however, they were unable to separate these two aspects in factor analysis. This could be because of the specificity of the investigated groups (students; $n=251$; mainly African American), where the dominating belief was Baptism (43\%), and half of the sample consisted of first year students.

Dudley and Cruise's ${ }^{42}$ conception follows Gordon Allport's ${ }^{43}$ view as a psychological tradition of the perception of religious maturity (in contrast to a theological one). Although Batson and Ventis ${ }^{44}$ argued that tools based on Allport's description of religious maturity record the fanaticism of engaged believers and proposed their own view based on a construct of tolerance, Dudley and Cruise, like many other researchers, criticized this conceptualization and chose Allport's theoretical conception. ${ }^{45}$ According to Allport, ${ }^{46}$ a religiously mature individual differentiates his/her feelings according to a critical evaluation of beliefs, not their literal interpretation. These feelings have a dynamic character due to their formation and maturation over time. A consequence of religious maturity is the individual creation of moral integrity. Being aware of the fact that some existential

39 R. L. Dudley - R. J. Cruise, "Measuring Religious Maturity..."; Paul J. Watson, "Religious Maturity Scale", in: Peter C. Hill - Ralph W. Hood Jr. (eds.), Measures of Religiosity, Birmingham: Religious Education Press 1999, 142-144.

40 Tiago Baltazar - Ron Coffen, "The Role of Doubt in Religious Identity Development and Psychological Maturity", Journal of Research on Christian Education 20, 2011, 182-194.

41 Margaret E. Cole - Robert A. Wortham, "The Dudley and Cruise Religious Maturity Scale: A Critical Evaluation", The Social Science Journal 37/3, 2000, 445-452.

42 R. L. Dudley - R. J. Cruise, "Measuring Religious Maturity...".

43 Gordon W. Allport, The Individual and His Religion, New York: Macmillan 1950.

44 Charles D. Batson - W. Larry Ventis, The Religious Experience: A SocialPsychological Perspective, New York: Oxford University Press 1982.

45 R. L. Dudley - R. J. Cruise, "Measuring Religious Maturity...".

46 G. W. Allport, The Individual... 
questions lack answers results in the formation of a tolerant attitude towards different beliefs. Due to the fact that empirical verification of the content of the beliefs of an individual is not possible, the feelings of the individual are heuristically characterized.

The flexibility of a system of beliefs and the readiness of the person to assimilate new data suggest that religious maturity can be treated as an adaptive trait. ${ }^{47}$ Additionally, it has been shown that in the Christian population, religious maturity supports positive strategies of religious coping, correlating negatively with negative strategies and maladjustment. ${ }^{48} \mathrm{It}$ also remains in a positive relationship with participation in activities connected to social justice and civic engagement, ${ }^{49}$ and in a negative relationship with Right-Wing authoritarianism. ${ }^{50}$ In the elderly it enables a decrease in the psychological distress associated with stressful life situations. ${ }^{51}$

A religiously mature individual engaged in his/her beliefs and values will, to a greater extent than a religiously immature person, experience strong feelings associated with these beliefs and values. Despite the fact that spirituality and religiousness are disjointed categories, emotional engagement in a bond with a sacred transcendent entity enables spiritual experiences focused on religious content, which remains a crucial source of spiritual feelings. ${ }^{52}$ The open-mindedness that accompanies religious maturity is associated with spiritual transcendence. This transcendence is understood as the ability of a person to change his/her current perspective and adopt a broader overview of reality. ${ }^{53}$

47 G. W. Allport, The Individual...; R. L. Dudley - R. J. Cruise, "Measuring Religious Maturity...”; P. J. Watson, "Religious Maturity Scale...".

48 Joshua J. Knabb - Anna Grigorian-Routon, "The Role of Experiential Avoidance in the Relationship between Faith Maturity, Religious Coping, and Psychological Adjustment among Christian University Students", Mental Health, Religion and Culture 17, 2014, 458-469.

49 Christine Kozlowski - Joseph R. Ferrari - Charlynn Odahl, "Social Justice and Faith Maturity: Exploring Whether Religious Beliefs Impact Civic Engagement”, Education 134/4, 2014, 427-432.

50 Gary K. Leak - Brandy A. Randall, "Clarification of the Link between Right-Wing Authoritarianism and Religiousness: The Role of Religious Maturity", Journal for the Scientific Study of Religion 34/2, 1995, 245-252.

51 Bruce E. Atkinson - H. Newton Malony, "Religious Maturity and Psychological Distress among Older Christian Women", The International Journal for the Psychology of Religion 4, 1994, 165-179.

52 Gabriel S. Dy-Liacco - Ralph L. Piedmont - Nichole A. Murray-Swank et al., "Spirituality and Religiosity as Cross-Cultural Aspects of Human Experience", Psychology of Religion and Spirituality 1/1, 2009, 35-52; Hawlin W. Jong, "Mindfulness and Spirituality as Predictors of Personal Maturity beyond the Influence of Personality Traits", Mental Health, Religion and Culture 16/1, 2013, 38-57.

53 R. L. Piedmont, "Does Spirituality Represent...". 
Religious maturity is, therefore, a trait that is conducive to the development of spirituality through the elimination of fundamentalist and dogmatic cognitive schemes. A readiness to change one's current beliefs neutralizes the fear of encountering feelings and beliefs stemming from intense spiritual experiences different from currently professed beliefs. Among Christian fundamentalists, a negative relationship between aspects of religious maturity (awareness of God, realistic acceptance of difficult feelings about God) and the experience of shame is observed. ${ }^{54}$ Moreover, by not unreflectively accepting an assimilated scheme, a religiously mature person is able to seek spiritual practices outside the native tradition. The theoretical relationship between religious maturity and mysticism would therefore indicate that religiously mature believers manifest a higher tendency to undergo mystical experiences whose contents are variable and culturally heterogeneous or, at least, not necessarily connected with their native culture.

\section{Method}

In this study, we used the following two research tools that we adapted ourselves: the Religious Maturity Scale by R. L. Dudley and R. J. Cruise ${ }^{55}$ (two versions were prepared - a Rodnovery one as well as a Christian one) and the Mysticism Scale: Research Form D (M Scale) developed by R. W. Hood Jr. ${ }^{56}$ We also used a questionnaire with socio-demographic data.

The Religious Maturity Scale is a questionnaire that includes 11 items. Two versions of the tool were constructed due to the occurrence of the categories "Churches" and "God" in the questionnaire, which were retained in the version for Catholics. In the version for Slavic Neopagans, however, they were replaced by the categories "Religious Associations" and "Gods", which more adequately fit the content of beliefs and the manner of religious functioning representative of this group. After conducting a homogeneity analysis of the scale (Cronbach's alpha), a decision was made to exclude item no. 7 (Religious Associations / Churches should concentrate on proclaiming the gospel [translated as "own ideas"] and not become involved in trying to change society through social or political action) from further analysis. The low discriminating power of this item probably resulted from the difference in the function that Churches and Religious Associations have in Polish society, the society in which the

54 Kathryn H. Keller - Debra Mollen - Lisa H. Rosen, "Spiritual Maturity as a Moderator of the Relationship Between Christian Fundamentalism and Shame", Journal of Psychology and Theology 43/1, 2015, 34-46.

55 R. L. Dudley - R. J. Cruise, "Measuring Religious Maturity...".

56 R. W. Hood Jr., "The Construction...". 
study was conducted, as well as in Anglo-Saxon culture, the culture in which the tool was originally developed.

The Mysticism Scale: Research Form D (M Scale) is a scale that includes 8 subscales and 32 items (4 items per subscale).

In the socio-demographic questionnaire, participants were asked about their gender ( 2 categories), age (in years), and education (2 categories) with reference to the Polish system of formal education. In the case of education, the first category referred to the completion of 12 years or less of formal education, whereas the second category referred to the completion of more than 12 years of formal education (which corresponds to a university education).

The study was conducted from June to October 2015. Individuals who expressed a desire to participate in the study filled out the following questionnaires (in order): the Religious Maturity Scale, the Mysticism Scale: Research Form D, and the socio-demographic questionnaire. The study was conducted online. Questionnaires with an invitation to take part in the study as well as instructions were distributed via social networks in websites frequently visited by Rodnovers and Catholics (the comparative group - Catholicism is the dominant faith in Poland). Two versions of the Religious Maturity Scale were distributed (the Rodnovery and the Catholic one).

119 people took part in the study; 69 of them declared that they belonged to the Rodnovery faith (Neopagans; Slavic Natives), and 50 were Catholic. The minimum age of the participants was 18 years (in Poland this means being of legal age). The mean age in the group of Rodnovers was 28 (ranging from 18 to 56; $\mathrm{SD}=9,18$ ), while in the group of Catholics it was 24 (ranging from 18 to 45 ; $\mathrm{SD}=5,01$ ). $35.3 \%$ of all studied individuals were male (42 people), whereas $64.7 \%$ were female ( 77 people). 58 people $(48.7 \%)$ had completed 12 years or less of formal education while $55(46.2 \%)$ had completed over 12 years of formal education. In the case of 6 people $(5.1 \%)$, there was no data with respect to their education level. 


\section{Results}

The statistical analysis was realized in two stages. During the first stage, correlations between religious maturity and mysticism as well as differences between the two groups (Rodnovery vs. Catholic) were analyzed. During the second stage, a binary logistic regression was applied in order to define the predictors of belonging to the group of Rodnovers.

\subsection{Descriptive Analyses}

Religious Maturity. The subjects displayed a rather high level of religious maturity. Their mean score was 36.13 out of $50(S D=6.06$; $M d n=37)$. The Shapiro-Wilk test for the normality of distribution turned out to be statistically significant for religious maturity (Shapiro-Wilk statistic $=0.95$; $\mathrm{p}<.001$; left skewed). The median for males $(M d n=36)$ and females $(M d n=37)$ was similar (the Mann-Whitney test was not statistically significant). We noted similar results for both Rodnovers and Catholics. There was no statistically significant correlation between age and religious maturity across the entire investigated sample, nor in the case of the Catholic group alone; however, this relationship turned out to be significant in the group of Rodnovers $\left(r_{\mathrm{s}}=-.259, p=.032\right)$, though it should be emphasized that the correlation was weak. When it comes to education, the level of religious maturity turned out to be higher in the group of individuals who had completed 12 years or less of formal education $(M d n=38)$ in comparison to the participants who had studied longer $(M d n=35 ; U=1142$, $p=.003, r=.27)$. A similar difference was observed in the group of Rodnovers $\left(M d n_{<12 \text { years }}=38 ; M d n_{>12 \text { years }}=36 ; U=340.50, p=.009, r=.324\right)$. In the group of Catholics, this difference was statistically insignificant.

Mysticism. The mean score for mysticism in the investigated sample was 96.97 out of $160(S D=27,27 ; M d n=97)$. This variable was normally distributed (insignificant Shaphiro-Wilk test). Males $(M=95.67 ; S D=30.12)$ and females $(M=97.68 ; S D=25.76)$ were similar in this dimension (the $t$ test was not statistically significant). Furthermore, no differences between males and females were observed with regards to mysticism, either in the group of Rodnovers or the group of Catholics. The correlation between age and mysticism across the entire sample was statistically insignificant, as it was in the group of Rodnovers; in the Catholic group, however, it turned out to be significant ( $r=.34, p=.016)$. The level of mysticism was similar (insignificant $t$ test) in the groups that differed with regard to level of education.

The global score for mysticism is compiled from the results of the eight detailed dimensions. These dimensions are: Ego Quality, Unifying Quality, 
Inner Subjective Quality, Temporal/Spatial Quality, Noetic Quality, Ineffability, Positive Affect, and Religious Quality. Table 1 shows the basic descriptive statistics for religious maturity and mysticism, both for the global score and for its eight dimensions.

\begin{tabular}{|l|r|r|r|r|r|r|}
\hline Variable & \multicolumn{1}{|c|}{ M } & \multicolumn{1}{c|}{ SD } & \multicolumn{1}{c|}{ Min } & \multicolumn{1}{c|}{ Max } & Skewness & Kurtosis \\
\hline Religious Maturity & \multicolumn{1}{|c|}{66.13} & 6.06 & 18.00 & 47.00 & -.87 & .90 \\
\hline Mysticism & 96.97 & 27.27 & 32.00 & 156.00 & -.17 & -.30 \\
\hline Ego Quality & 11.44 & 4.76 & 4.00 & 20.00 & -.04 & -1.04 \\
\hline Unifying Quality & 11.03 & 5.26 & 4.00 & 20.00 & .19 & -1.20 \\
\hline Inner Subjective Quality & 8.86 & 4.89 & 4.00 & 20.00 & .76 & -.55 \\
\hline Temporal/Spatial Quality & 12.45 & 4.98 & 4.00 & 20.00 & -.08 & -1.08 \\
\hline Noetic Quality & 10.93 & 4.23 & 4.00 & 20.00 & .25 & -.52 \\
\hline Ineffability & 14.94 & 4.63 & 4.00 & 20.00 & -.67 & -.71 \\
\hline Positive Affect & 13.87 & 4.37 & 4.00 & 20.00 & -.55 & -.70 \\
\hline Religious Quality & 13.44 & 4.30 & 4.00 & 20.00 & -.28 & -.86 \\
\hline
\end{tabular}

Tab. 1. Basic descriptive statistics for religious maturity and mysticism (total and for its 8 dimensions); $N=119$.

No statistically significant differences within the particular dimensions of mysticism were observed between females and males or between the groups differing with regard to level of education. Age correlated weakly with one dimension of mysticism, i.e. Noetic Quality $\left(r_{\mathrm{s}}=.22 ; p=.019\right)$.

\subsection{Analysis of correlations and intergroup differences}

The analysis of the correlations between religious maturity and mysticism was conducted for both the entire sample as well as separately for the groups of Slavic Neopagans and Catholics (Table 2). Statistically significant correlations could be observed exclusively between religious maturity and two dimensions of mysticism, i.e. Temporal/Spatial Quality $\left(r_{\mathrm{s}}=-.29\right.$; $p=.041)$ and Noetic Quality $\left(r_{\mathrm{s}}=-.30 ; p=.038\right)$, but only in the group of Catholics. Thus, it can be stated that religious maturity and mysticism are two different variables that do not remain in a close relationship with each other, and that the scope of meaning of these two constructs is different. Moderate negative relationships between religious maturity and Temporal/ Spatial Quality as well as Noetic Quality may express a tendency of individuals (Catholics) with low religious maturity to lose their sense of time and space and to believe in the acquisition of intuitive knowledge about the world during a spiritual experience. This means that Catholics with less 
mature and therefore more fundamentalist religious attitudes have a greater tendency to transcendentally cross the boundaries of everyday reality and to feel as if they have gained information, otherwise inaccessible, during such experiences. More religiously mature Catholics therefore lose this dichotomous perception of the world (human vs. divine sphere). This phenomenon was in no way observed in the case of Slavic Neopagans, for whom it is natural that the two spheres strongly interpenetrate each other.

\begin{tabular}{|c|c|c|c|c|c|c|c|c|c|c|}
\hline & & 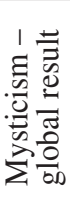 & 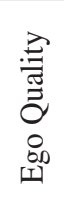 & 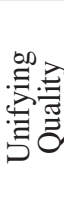 & 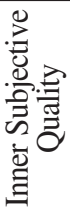 & 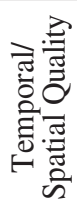 & 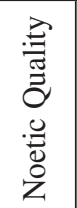 & 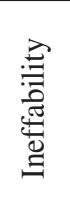 & 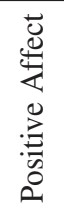 & 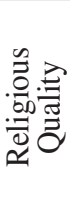 \\
\hline \multirow{3}{*}{ 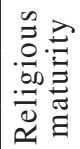 } & Entire sample & .00 & .00 & .18 & .04 & -.08 & -.16 & -.04 & .04 & -.05 \\
\hline & Slavic Neopagans & 10 & .09 & .21 & .06 & .02 & -.04 & .00 & .15 & .10 \\
\hline & Catholics & -.21 & -.16 & .06 & -.13 & $-.29^{*}$ & $-.30^{*}$ & -.09 & -.05 & -.19 \\
\hline
\end{tabular}

* Correlation is significant at the level of .05 (2-tailed).

Tab. 2. The correlation coefficient (Spearman's $r_{s}$ ) between religious maturity and mysticism in the entire research sample $(N=119)$ as well as in the group of Slavic Neopagans $(N=69)$ and Catholics $(N=50)$.

An analysis of the differences with regard to religious maturity between Slavic Neopagans and Catholics was also conducted. It turned out that the level of religious maturity did not differentiate the two groups. In the case of mysticism, although the global result did not differentiate the two groups, three dimensions of mysticism turned out to be significantly different. The level of Unifying Quality ( $U=1306.50 ; r=.21)$ was higher in the group of Slavic Neopagans $(M d n=12)$ in comparison to the Catholics $(M d n=8)$, as was the level of Inner Subjective Quality $\left(M d n_{\text {Neopagans }}=10\right.$, $\left.M d n_{\text {Catholics }}=5, U=982.00 ; r=.37\right)$, whereas the level of Religious Quality turned out to be higher in the group of Catholics in comparison to the group of Slavic Neopagans $\left(M d n_{\text {Neopagans }}=12 ; \quad M d n_{\text {Catholics }}=14.5\right.$; $U=1277.00 ; r=.22)$.

In addition, an analysis of the differences between Slavic Neopagans and Catholics for particular test items was conducted to find subtle distinctions between these groups. The following items for Unifying Quality Scale were statistically significant (with higher scores for Slavic Neopagans): 
- I have had an experience in which I realized the oneness of myself with all things $\left(M_{\text {Neopagans }}=4 ; M_{\text {Catholics }}=2 ; U=1312.00 ; p=.021 ; r=.21\right)$,

- I have never had an experience in which all things seemed to be unified into a single whole (reversed in scoring; $M_{\text {Neopagans }}=3 ; M_{\text {Catholics }}=1$; $U=1381.00 ; p=.05 ; r=.18)$.

In the case of the Inner Subjective Quality Scale, statistically significant differences between the two groups could be observed in:

- I have never had an experience in which I felt as if all things were alive (reversed in scoring; $M_{\text {Neopagans }}=2 ; M_{\text {Catholics }}=1 ; U=1174.00 ; p=.002$; $r=.29$ ),

- I have had an experience in which all things seemed to be conscious $\left(M_{\text {Neopagans }}=2 ; M_{\text {Catholics }}=1 ; U=1210.5 ; p=.002 ; r=.29\right)$,

- I have had an experience in which I felt nothing is ever really dead $\left(M_{\text {Neopagans }}=3 ; M_{\text {Catholics }}=1 ; U=979.5 ; p<.000 ; r=.39\right)$.

In turn, in the case of the Religious Quality Scale, significantly higher results were obtained by Catholics for the following two items:

- I have never experienced anything to be divine (reversed in scoring; $M_{\text {Neopagans }}=4 ; M_{\text {Catholics }}=5 ; U=1225.50 ; p=.004 ; r=.27$ ),

- I have had an experience which I knew to be sacred $\left(M_{\text {Neopagans }}=3\right.$; $\left.M_{\text {Catholics }}=4 ; U=1167.00 ; p=.002 ; r=.28\right)$.

The fact that Slavic Neopagans obtained higher results for the dimension of Unifying Quality and Inner Subjective Quality can be explained by referring to the content of their beliefs. They pertain to possessing a sense of being part of a reality that is a living organism. It corresponds to the Rodnovery belief of a sacral perception of nature, in which every constituent contains in itself a spiritual element. A human being is also seen here as an equal fragment of the natural environment. ${ }^{57}$ The omnipresence of spirituality from the perspective of Slavic Neopagans is linked to the mean score obtained by them on the Religious Quality Scale, which was lower than for the group of Catholics. This is because, for Rodnovers, spirituality is not something unusual or exceptional; therefore, it is not necessarily interpreted in a religious manner. In turn, the higher level of Religious Quality in the group of Catholics pertains to the specificity of the religious functioning of the two groups that were investigated. Catholics are used to congregating in temples for specific occasions, after which they separate from one another and return to everyday life. Their reality is, therefore, markedly divided into sacral (spiritual) and non-sacral spheres. For Slavic

57 M. Strutyński, Neopogaństwo..., 99. 
Neopagans, however, this division is much weaker, because in their case their entire reality (nature) remains sacred, not only one of its specific fragments (church) ${ }^{58}$ As a result, spiritual experiences are, for Slavic Neopagans, something natural, something they can encounter anytime and anywhere, as opposed to Catholics, who are open to mystical experiences mainly in a specific place (church) and at a specific time (service, holy mass).

\subsection{Binary logistic regression analysis}

The model. In order to determine which variables were significant predictors of belonging to the group of contemporary Slavic Neopagans (coded: 1 for Neopagans and 0 for non-Neopagans), a binary logistic regression analysis was applied. The logistic regression model was developed for the following variables: religious maturity, mysticism treated globally, gender (coded: 0 for males and 1 for females), age (reported in years), and education level (coded: 0 for 12 years or less of formal education and 1 for more than 12 years of formal education). We also decided to include the interaction of two variables - religious maturity and mysticism - in the model. The dimensions of mysticism were not included in the model, due to the high correlations between them. The enter method was used. The obtained results are presented in Table 3 .

\begin{tabular}{|l|r|r|r|c|}
\hline Predictors & $\mathbf{B}$ & Wald & Odd's ratio & p \\
\hline Religious maturity & -.27 & 2.33 & .77 & .127 \\
\hline Mysticism & -.11 & 3.25 & .89 & .072 \\
\hline Gender & -1.53 & 8.44 & .22 & .004 \\
\hline Age & .09 & 5.28 & 1.10 & .022 \\
\hline Education & -.15 & .09 & .86 & .759 \\
\hline Religious maturity*Mysticism & .00 & 3.90 & 1.00 & .048 \\
\hline Constant & 7.66 & 1.51 & 2128.87 & .219 \\
\hline
\end{tabular}

Tab. 3. Summary of the logistic regression analysis for variables predicting participation in the Neopagan movement.

A test of the full model against a constant-only model was statistically significant, indicating that the predictors as a set reliably distinguished between Neopagans and Catholics $\left(\chi^{2}=31.67, p<.001\right.$ with $\left.\mathrm{df}=6\right)$. The goodness of fit of the full model was evaluated by means of the HosmerLemeshow test. The test compares the number of observed events to the

58 K. Kośnik, W poszukiwaniu..., 58. 
expected number of events in equally sized subgroups. ${ }^{59} \mathrm{~A} p$-value of 0.05 or less signifies that the hypothesis that the model fits the data can be rejected; thus, $p$-values above 0.05 are acceptable with higher $p$-values implying a better model fit. The results of the Hosmer-Lemeshow test for our model were as follows: $\chi^{2}=8.234, p=.412$. We can say that the proposed model fits the data quite well. The Cox-Snell pseudo $R^{2}$ was 0.24 and the Nagelkerke $R^{2}$ was 0.32 . We can conclude that between 24 and 32 percent of the variation in the dependent variable can be explained by the model. The overall prediction success was $75.9 \%$ (75.8\% for Neopagans and $76.0 \%$ for Catholics).

The interpretation of the model. Initially, we assumed that the main predictor of belonging to the group of Slavic Neopagans would be the level of mysticism. Neither the level of religious maturity nor the level of mysticism were significant here. The level of education did not significantly influence the probability of belonging to the group of Rodnovers. The variables that turned out to be meaningful were gender, age, and the interaction between religious maturity and mysticism. Males had a greater chance of belonging to the group of Slavic Neopagans $(O R=.22$; males were coded as 0$)$. This probability increased with age $(O R=1.10)$.

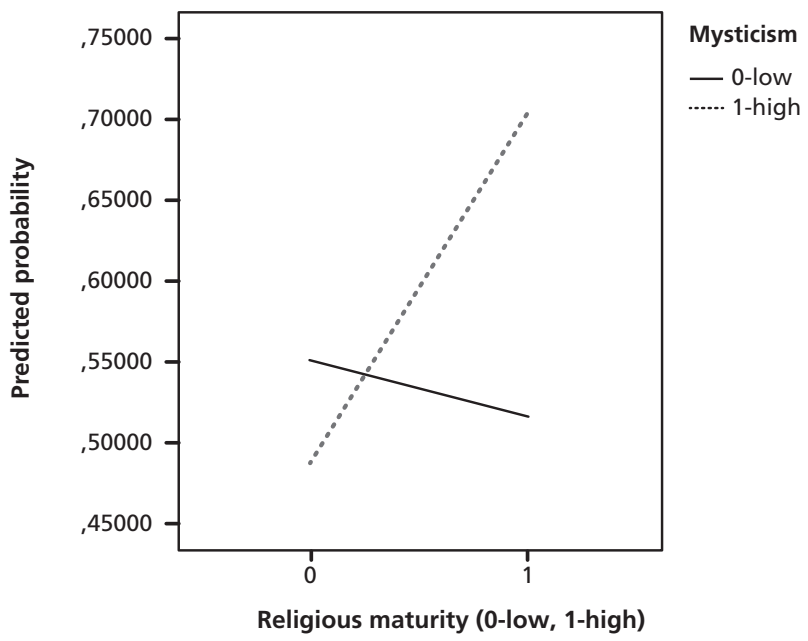

Fig. 1. The interaction between religious maturity and mysticism.

59 David W. Hosmer Jr. - Stanley Lemeshow - Rodney X. Sturdivant, Applied Logistic Regression, Hoboken: John Wiley and Sons 2013. 
The most interesting result is the significant interaction between religious maturity and mysticism (see Figure 1). As can be seen, the probability of belonging to the group of Slavic Neopagans increases with the level of religious maturity - however, only on the condition that it is accompanied by a high level of mysticism. This result does not confirm the common belief that the Rodnovery movement attracts rather young individuals who seek a religious identity. Rather, it could indicate that choosing Slavic Neopaganism as one's religion is usually a conscious, mature decision that is dictated by the internal (spiritual) needs of an individual.

\section{Discussion}

The interpretation of the obtained results reveals fundamental differences in the manner of religious functioning between Slavic Neopagans and Catholics (the dominant religious group in Polish society). The comparative analyses draw an image of a Slavic Neopagan as a person who remains in an intense relationship with the natural environment. This image is closely connected with the content of Rodnovery beliefs. ${ }^{60}$ Due to this specific relationship, a Slavic Neopagan's spiritual functioning is not divided into the spheres of the sacred and profane, as it is in the case of the Catholic faith; rather, it is a coherent whole in which everyday life and spiritual ecstasy interpenetrate one another. Also, a declaration of belonging to the Rodnovery movement is not, as might be intuitively expected, necessarily an expression of a youthful, dynamic exploration of reality. It can be a mature and thought-through decision, which is suggested by the increase in the probability of belonging to the group of Slavic Neopagans being linked with increasing age as well as with an increase in the interaction between religious maturity and mysticism. The spiritual engagement of Slavic Neopagans together with their open-mindedness as well as their readiness to change their views indicate that the choice of this religion is not just a seasonal trend, but a deeper decision satisfying personal needs. Another interesting observation is the greater probability of belonging to the Rodnovery faith in the case of males rather than females. It can be stated that Rodnovery, while promoting natural values, such as communing with "wild" nature, provides the opportunity to realize an identity based upon the gender archetype of a strong and proud "warrior". 61

Some of our observations may be explained by the fact that the Rodnovers examined in our study are the first (converted) generation of

60 K. Kośnik, "Tożsamość współczesnych rodzimowierców...”; M. Strutyński, Neopogaństwo...

61 S. Simpson, "Men Constructing Masculinity...". 
contemporary Slavic Neopagans in Poland, while most Catholics were born into their religion. A conscious and voluntary decision to become a Rodnovery member seems to be connected with differences between these two religious groups in the case of scales of mysticism, while the choice of religion was an answer to one's individual spiritual needs (especially a union with nature). Although Slavic Neopagans and Catholics were not differentiated by their respective levels of religious maturity, the results of binary logistic regression analysis indicate that the combination of religious maturity and mysticism observed as a predictor of participation in the Rodnovery movement is an expression of the will to seek spiritual experiences outside of "native" religion. While Slavic Neopaganism can be treated as a native religion in the sense of ethnicity, it is not "native" in terms of one's nurture - as no contemporary Polish Rodnovers have been born into this recently-reconstructed religious tradition. The specificity of Slavic Neopagan spirituality, however, cannot be directly generalized and used for the interpretation of all kinds of converts due to considerable differences between the contents of beliefs of particular religious groups.

It should be noted that our research was conducted on a relatively small sample and without randomization, which presents limitations with respect to generalizing its conclusions. It is possible that overall Slavic Neopagan spirituality differs from spirituality present in specific Rodnovery religious organizations and the currents of this religion. Future continuations or replications of this preliminary study should therefore attempt to engage a larger number of participants drawn from each officially-registered Rodnovery organization as well as from non-official Rodnovery associations to allow comparison between their members and reveal potential internal differences within this religious group.

A psychological analysis of the phenomenon of Slavic Neopaganism encounters difficulties predominantly associated with the fact that little information is known about this belief system. Available knowledge on this phenomenon is constructed on the basis of Religious Studies. A consequence of this is that the questions formulated by such studies differ from those that would be posed by psychology and its methodology. Religious Studies experts, of course, often refer to data on human behavior and mental phenomena; however, they do not present them in a manner psychologists are used to. This suggests that further, deeper studies on Slavic Neopaganism need to be conducted. Besides a quantitative approach, such studies should also employ qualitative tools and methods that would enable the discovery and understanding of specific mental contents, these constituting objects of self-identification for particular individuals. 


\section{SUMMARY}

\section{A Preliminary Quantitative Study of the Mysticism and Religious Maturity of Contemporary Slavic Neopagans in Poland}

In the article we present the results of our research on the spirituality of Slavic Neopagans in Poland. Spirituality is understood here according to the concept of mysticism described by R. W. Hood Jr. (1975). As the second main theoretical tool, we use the concept of religious maturity put forward by R. L. Dudley and R. J. Cruise (1990). A questionnaire survey, conducted online on a sample of Slavic Neopagans and Catholics, showed statistically significant differences between the groups in three out of the eight subscales of mysticism (Unifying Quality, Inner Subjective Quality and Religious Quality), while at the same time showing a lack of significant differences with respect to religious maturity. Further analysis by means of binary logistic regression made it possible to determine predictors of belonging to the group of Slavic Neopagans (75.8\% of the cases). In the regression model, the separate treatment of mysticism and religious maturity turned out to be insignificant, whereas gender, age, and the interaction between religious maturity and mysticism significantly differentiated the investigated groups.

Keywords: spirituality; mysticism; religious maturity; Slavic Neopaganism.

Faculty of Psychology and Cognitive Science Adam Mickiewicz University in Poznań ul. A. Szamarzewskiego 89/AB 60-568 Poznań

Poland

Faculty of Psychology and Cognitive Science ELŻBIETA HORNOWSKA Adam Mickiewicz University in Poznań ul. A. Szamarzewskiego 89/AB elzbieta.hornowska@amu.edu.pl 60-568 Poznań

Poland

konrad.kosnik@gmail.com

KONRAD KOŚNIK 